\title{
Skip the (Capitalist) Intermediaries: Freedom, Democracy, and Participation in the Economy and Culture
}

\author{
Forrest Perry
}

\author{
Department of Philosophy, Saint Xavier University, Chicago, U.S., perry@sxu.edu
}

\begin{abstract}
A significant parallel can be drawn between a socialist argument about how to regulate property in the means of production and the liberal theorist Lawrence Lessig's argument about how to regulate property in ideas. The two are particularly alike in the emphasis they place on the kind of participation-and the resulting freedom and democracy-enabled by having access to the means of production. Highlighting the parallel could help socialists and liberal theorists of intellectual property to see how they might advance each other's causes: socialism could eliminate the threat of privatization of the means of producing culture that liberals like Lessig rightly worry about; if the arguments about ownership of ideas made by Lessig and others like him end up gaining currency, then arguments about ownership of the means of production made by socialist theorists could have more resonance with larger numbers of people than is currently the case.
\end{abstract}

Keywords: socialism, capitalism, Internet, copyright, means of production

Acknowledgement: I would like to thank Tony Smith (Department of Philosophy and Religious Studies and Department of Political Science, lowa State University) for his insightful comments on a draft of this article.

There is "Communism at the core of our Constitution's protection of intellectual property" (Lessig 2006, 184). The prominent Internet law theorist Lawrence Lessig makes this claim in his discussion of the "copyright clause" of the U.S. Constitution, which in turn is part of his discussion of how to regulate intellectual property. He makes this striking claim only in passing, though. He does not elaborate on it and does not at any other point in his work suggest that there is a parallel to be drawn between his ideas about intellectual property and communist (or socialist) ideas about property. In what are among the most trenchant critiques of efforts to privatize the intellectual commons, he highlights as a major culprit what socialists would readily call the capitalist imperative, but he himself never uses that term and he never identifies himself as a socialist. He doesn't even call capitalism into question. ${ }^{1}$ There are other liberal theorists of intellectual property who provide critiques like Lessig's without seeing them as critiques of capitalism (the most prominent ones being Yochai Benkler and James Boyle $^{2}$ ). At this point, enough has been written to show that capitalism is at odds with the intellectual property regime envisioned by Lessig and liberal theorists like him. ${ }^{3}$ What I try to show in this paper is that there is little distance between the line of argument Lessig employs

\footnotetext{
${ }^{1}$ If anything, he champions it. This is not to say that he champions capitalism regardless of the form it takes. In Republic, Lost (2011), he is deeply critical of "crony capitalism." But so too are right-libertarian proponents of socalled free-market capitalism, as Lessig notes in an October 2011 interview (http://bit.ly/1qWLmcY, accessed on 2 See, for example, James Boyle, The Public Domain: Enclosing the Commons of the Mind (2008) and Yochai Benkler, The Wealth of Networks: How Social Production Transforms Markets and Freedom (2006). One of the reviewers of this article, Johan Söderberg, has rightly pointed out that Boyle does not fit squarely within the camp I'll be referring to as "Lessig and other liberal intellectual property theorists." As Söderberg notes, in being among the first to make a connection between enclosure of the intellectual commons and enclosure of the physical commons, Boyle situated his critique of the privatization of intellectual content within the larger and older regime of private property, thereby departing, at least somewhat, from the standard liberal analysis of intellectual property. See Boyle, "A Politics of Intellectual Property: Environmentalism for the Net?", 47, Duke Law Journal (1997).

${ }^{3}$ The most recent and comprehensive work to do so is Robert McChesney's Digital Disconnect: How Capitalism is Turning the Internet Against Democracy (2013). See also Tony Smith's incisive critique of The Wealth of Networks by Yochai Benkler, who, like Lessig, can be described as a prominent liberal theorist of the Internet (Smith 2012). See also Mosco 2004, Perelman 2002, Schiller 2006, and Suarez-Villa 2009.
} 
to justify a certain kind of regulation of property in ideas and the line of argument socialists can employ to justify a certain kind of regulation of property in the means of production.

Lessig sees privatization of the intellectual commons as a threat to the realization of what he has called both "free culture" and "democratic culture." ${ }^{4}$ Both terms refer to a culture that would be participatory in the sense that it would be shaped by the vast majority of people rather than a small minority. A socialist economy, or rather the kind of socialist economy l'll be describing in this paper, could also be described as participatory, free, and democratic. Lessig's argument concerning how to regulate intellectual property and the socialist argument I'll be presenting in this paper are alike, then, in that both support freedom and democracy, with freedom and democracy understood as having participation as one of their crucial components.

What's key to the parallel l'll be drawing in this paper is the kind of participation at issue in both arguments: it's the kind of participation that is enabled by having access to the means of production. It is the centrality of this kind of participation to Lessig's line of argument that makes me think it correct to say that there is something significantly socialist about what Lessig argues. However, that Lessig's argument is about participation of this sort is not obvious because he never singles the means of production out for discussion. He distinguishes tangible things, such as food and shelter, from ideas, which are intangible; he talks about different ways of regulating property in those different kinds of things; and in talking about how to regulate property in ideas, there's a way in which he is talking about the means of producing ideas. But he never actually uses the term means of production and never really discusses the means of production as a category separate from other objects of ownership. Re-casting his arguments about the regulation of intellectual property so as to reveal that they are about regulating the means of production will help to show that there are similarities between what Lessig argues and the socialist argument l'll be presenting.

In drawing parallels between these two lines of argument-showing that both are about increasing access to the means of production for the sake of enabling for all people the kind of participation required for freedom and democracy-one thing I show is that aspects of the arguments Lessig makes about ideas (intangible things) also apply to (tangible) means of production. In so doing, I reveal some incoherence in Lessig's arguments, for it is incoherent to affirm an argument in one context (having to do with ideas) and deny its application in another context (having to do with tangible means of production) that is like the first in all relevant respects. ${ }^{5}$ Criticizing Lessig is not the aim of what I do in this paper, however. ${ }^{6}$ The main reason I draw parallels between his line of argument and that of socialists is to show that liberal theorists of property like Lessig, on the one hand, and socialists, on the other hand, could benefit from seeing how each advances the cause of the other. ${ }^{7}$ Liberal intellectualproperty theorists like Lessig could benefit from seeing that the world socialists struggle to bring about-a world without capitalism and hence without privatization of the intellectual commons-is in all likelihood the only world in which a free and democratic culture can flourish. ${ }^{8}$ Thus, as Robert McChesney (2013) argues, achieving their aims will require that liberal intellectual-property theorists help to build "a broader political movement motivated by a general progressive agenda, not one specifically focused on the Internet or media" (220), which means they will need to overcome whatever reluctance they might have "to stick their toes into deeper political waters" and "grasp the nature of our times" (221)_our capitalist times.

\footnotetext{
${ }^{4}$ Lessig uses the term free culture in Free Culture (2004) and the term democratic culture in Remix (2008), the latter being the last book he wrote that touches on the issue of intellectual property.

${ }^{5}$ My thanks to Tony Smith for providing me with this formulation in email correspondence.

${ }_{7}^{6}$ Despite the criticisms, I deeply admire the work Lessig has done and continues to do.

7 Cf. Purdy's argument (Purdy 2005) that theorists of property in general and theorists of intellectual property more specifically could benefit from seeing themselves as championing a "common cause" and belonging to the same "movement or tradition" (Purdy 2005, 1283).

${ }^{8}$ In this paper, I do not address the concern that innovation, which is clearly of value to Lessig and those who are attracted to his vision of a "free culture," would suffer under a socialist regime of property. Addressing that concern, although not difficult to do, would require that I add considerably to the length of this paper. Readers interested in the issue should look at Kotz 2002. See also Schweickart 1996, 127-36 and Hardt and Negri 2004, 30102.
} 
Likewise, socialists should take note of the arguments of liberal theorists like Lessig because, given the parallels between the arguments advanced by each, if the arguments about ownership of ideas made by Lessig and others like him end up gaining currency, then arguments about ownership of the means of production made by socialist theorists could have more resonance with larger numbers of people than is currently the case-a situation that, should it arise, socialists should be prepared to take advantage of. However, socialists should not just hope that a victory for liberal intellectual-property theorists will increase the likelihood of people paying attention to socialist ideas, especially if it is the case that no such victory will occur if the capitalist system is not transformed into something fundamentally different, but also because, as McChesney argues, "efforts to reform or replace capitalism but leave the Internet giants riding high will not reform or replace really existing capitalism. [...] The entire range of Internet and media issues must be in the center of any credible popular democratic uprising. Given the extent to which the digital revolution permeates and defines nearly every aspect of our social lives, any other course would be absurd" $(2013,223)$.

The argument I develop in this paper is divided into four sections. In Section 1, I will argue that in order to enjoy freedom and democracy, people must be able to participate in shaping the social conditions that shape them and that in order to do this, they must be able to participate in making decisions about the purposes that the means of production will serve. I will then present a model of socialism under which people would participate in decision-making of this sort in the economic sphere. ${ }^{9}$ In Section 2, I lay out Lessig's argument that if people are to enjoy freedom and democracy in the cultural sphere-or to have what he sometimes calls "free culture" and at other times "democratic culture"-they must be able to participate in controlling the means of producing culture. As already noted, Lessig himself does not use the term means of production. I make use of that term in my re-casting of his arguments so as to highlight, in Section 3, one of the parallels between Lessig's thinking and that of socialists, who do use the term. After drawing those parallels, I build upon the discussion of ideas as a means of production-the "raw material" of future ideas-to make the argument that if we are to achieve the free, democratic, and participatory culture advocated by Lessig et. al., we need to take heed of and challenge privatization not just of the intellectual commonswhich comprises the ideas that constitute the "raw material" of culture-but also of the Internet, a crucial instrument of producing and distributing ideas. My focus here will be on the Internet's "pipes," which constitute the medium through which people transmit their activity on the Internet. ${ }^{10}$ I wrap things up in Section 4 with some remarks about why one of the mottos employed by certain advocates of free and democratic culture-_skip the intermediaries," i.e., bypass the holders of copyright and their lawyers-should be extended to include the idea of skipping the capitalist intermediaries, that is, overcoming the system of capitalism, in which control over the means of production is concentrated in the hands of the few.

\section{1.}

In an article that makes arguments very much in line with the ones made by Lessig that we'll be looking at in Section 2, Jack Balkin offers the following explanation for why "democratic cultural participation" is important:

culture is a source of the self. Human beings are made out of culture. A democratic culture is valuable because it gives ordinary people a fair opportunity to participate in the

\footnotetext{
${ }^{9}$ At no point in my analysis do I mean to suggest that the economic sphere and the cultural sphere I will be distinguishing it from are ontologically separate societal domains, but I am afraid there will be times when I do just that and that the only way I could clarify my position would be to enter into a lengthy discussion about how the concepts of economy and culture are distinct even though they also shade imperceptibly into each other. Such a discussion would go well beyond the scope of this paper.

${ }^{10} \mathrm{Cf}$. Balkin, who defines the "pipes" of the Internet as the "medium of transmission, whether it be spectrum, networks, telephone wires, or cables. Technologies of distribution are the 'pipes' through which content travels. The key question in the digital age is who will control these "pipes"' $(2004,17)$. What I do not consider in my paper-because doing so would require going into technical details that would extend considerably the length of the paper-is how code and the "architecture" of the Internet are manipulated to serve the interests of powerful companies. Excellent analyses of that issue can be found in Lessig 2001, Lessig 2006, and van Schewick 2010.
} 
creation and evolution of the processes of meaning-making that shape them and become part of them; a democratic culture is valuable because it gives ordinary people a say in the progress and development of the cultural forces that in turn produce them. (Balkin 2004, 33)

Thus having a democratic culture is important because it is one in which people participate in shaping the social conditions-more specifically, the "cultural forces"-that shape them. Such a culture, Balkin adds, is one in which freedom of speech flourishes (36-37). Whereas Balkin speaks of the kind of participation described above in terms of freedom of speech, in this section I will connect such participation to freedom understood more generally by situating the idea of producing or developing the self that Balkin talks about above within a theory of freedom that has democratic participation as one of its essential elements.

Democratic participation not just in the sphere of culture, though. Balkin, Lessig, and other liberal theorists of intellectual property stress how important it is to have a democratic, participatory culture if we're to have democracy more generally. For instance, Balkin writes,

The point of democracy, as its name implies, is to put power in the hands of the people, to give ordinary people some measure of control over the forces that shape their lives and some degree of say about how the world around them develops. [Law] and governance are only parts of this world. Culture is an even larger part, and in some ways it has an even more capacious role in structuring our lives. (Balkin 2004, 36)

The economy has perhaps an even larger role. Regardless of whether it does, the kind of economy one lives in plays a crucial role in shaping one's self. ${ }^{11}$ Thus, if our concern is to live in a democratic society, we need to pay attention to participation not just in the cultural but also the economic sphere. In both cases, this means examining participation that takes the form of determining the purposes that the means of production will serve. Participation in controlling the cultural means of production will be my focus in Section 2. It's the economic means of production and hence the economic sphere that l'll be focusing on in this section. I'll do that through a brief examination of a socialist economy characterized by freedom, democracy, and participation. First, though, I will show how freedom, democracy, and participation-more specifically, participation in shaping the conditions that shape us by participating in controlling the means of production-can be understood as closely connected to each other.

To show how freedom, democracy, and participation are connected to each other, I draw on the accounts of freedom given by the philosopher Carol Gould and the legal theorist Jedidiah Purdy. ${ }^{12}$ For Gould, freedom is a matter of exercising and developing human capacities that contribute to "self-development" or "self-realization." Whether, and in what ways, we develop ourselves depends on whether we have access to "the social and material means for realizing purposes" (Gould 1988, 35). In many cases, these means are employed in "common activity," which Gould defines as "activity in which a number of individuals join together to effect a given end" or purpose (Gould 1988, 78). In the many cases where these means are employed in "common activity"-and where the focus of this section is concerned, namely, economic production, this is more often the case than not-access to those means exercised by everyone engaged in that activity consists, or ought to consist, in an equal right to participate in making decisions about that activity (Gould 1988, 79, 84). If freedom requires having access to the means for realizing purposes, and if where common activity is concerned access to those means takes the form of participation in decision-making about the

\footnotetext{
${ }^{11}$ Here would be one place where a discussion of the relationship between economy and culture would be in order were it not for the fact that such a discussion would take us too far afield from the focus of this paper.

${ }_{12}$ Much could be said about the concept of freedom I employ in this paper. My understanding of it is has been informed most by the work of John Dewey, but readers will have little difficulty locating aspects of it in the thinking of many other theorists. The "freedom-promoting approach" Purdy presents is one that many scholars nowadays would closely associate with discourse about "capabilities." Purdy argues that the approach has its origins in Adam Smith and that "its theoretical underpinnings are experiencing a revival, most prominently in the thought of Amartya Sen"-and, we could add, Martha Nussbaum (Purdy 2005, 72).
} 
purposes to be served by that activity, then participation of this sort is a crucial component of freedom. Purdy stresses the importance of such participation in his discussion of what he calls a "freedom-promoting approach to property." He stresses the importance of participation, "the capability to engage with and reform institutions," by dubbing it a "meta-capability," which he defines as a capability for "revising one's context" and thereby "affect[ing] the scope of one's future capabilities" (Purdy 2005, 46, 47, 56). For Gould and Purdy alike, then, participation is a crucial component of freedom. It is also, and more obviously, a crucial component of democracy. Oversimplifying a bit, it can be said that conditions are more democratic the more widespread participation is in determining those conditions (cf. Gould 1988, 90, 1-2). The more people there are who participate in the formation of political community-whether that be through voting, serving as a member of a local school board, or building movements - the more democratic the political sphere is. The more people there are who participate in directing business activity, the more democratic the economic sphere is. And so on.

It's[possessive or It is?] participation in determining the economic conditions under which we live by participating in controlling the means of production that I focus on in the rest of this section. As Gould says, whether we develop ourselves and hence whether we're free depends on our having access to what she calls "the social and material means for realizing purposes". Where economic activity, in much of today's world is concerned, a small minority controls those means (the means of production). Wherever the capitalist mode of production is dominant, the vast majority of people are excluded from participating in making decisions about the purposes to which the means of production will be put, the ends they will serve. ${ }^{13}$ Things would be different under a democratic form of socialism.

I will discuss two levels at which people under socialism might participate in controlling the means of production-democratically and in the service of freedom. I will be talking here about David Schweickart's model of Economic Democracy. His is a model of socialism with markets, but the market dimension of his model is not of interest to me here. ${ }^{14}$ Participation is. There are other forms of socialism that emphasize participation, but with my aim being to indicate only briefly the levels at which participation could take place within a socialist alternative to capitalism, looking at just one model is sufficient. ${ }^{15}$

On Schweickart's model, the workplace is one level at which people can participate in controlling the means of production. They do so by making decisions about what to produce and how to produce it, with the latter including decisions about who will do what and using what methods. They also make decisions about hiring and firing, promotion and discipline, how much to produce, the price at which to sell what they produce, and how the money generated from sales will be distributed (Schweickart 2002, 47; cf. Wolff 2012, 123-37). ${ }^{16}$ In short, they make decisions about the various ends that the means of production will serve.

\footnotetext{
${ }^{13}$ Dewey explains this form of exclusion well when he writes that under capitalism, "economic associations are fixed in ways which exclude most of the workers in them from taking part in their management. The subordination of the enterprises to pecuniary profit reacts to make the workers 'hands' only. Their hearts and brains are not engaged. They execute plans which they do not form, and of whose meaning and intent they are ignorantbeyond the fact that these plans make a profit for others and secure a wage for themselves" (Dewey 1999 [1930], 64). For a discussion of this separation, see Braverman 1998 (1974). See also Young 1990, 216, 221.

${ }^{14} \mathrm{I}$ am well aware that there is debate about whether economic systems that include markets, such as the one proposed by Schweickart, can be genuinely socialist, but I will not enter into that debate here. Those interested in that debate might want to look at Ollmann 1998.

${ }^{15}$ For a different model of market socialism, see Howard 2000. For a model of socialism without markets, see Albert 2003. For a recently published exposition of a model similar to Schweickart's, see Jossa 2014 (special thanks to Joss Winn for directing my attention to this book).

${ }^{16}$ Michael Albert argues that if we are to break down this separation enough so that everyone in an enterprise participates equally in decision-making, then it will be necessary to take care to create "balanced job complexes where everyone typically does many levels of tasks" (Albert 2003, 105). It's important to have balanced job complexes, Albert explains, so that when "the workers come together in their workers' councils [...], there is no subset of workers whose conditions have prepared them better and left them more energetic or provided them greater relevant information or skills relative to everyone else, such that they will predictably dominate debate and outcomes." Ibid., 106. For Schweickart's criticism of balanced job complexes in particular, and Albert's "Parecon" model more generally, see http://orion.it.luc.edu/ dschwei/parecon.htm (accessed on March 15, 13). You can find Albert's response to the criticism and Schweickart's response to that response here: http://www.ecodema.org/archives/000171.html (accessed on March 15, 2013).
} 
Under Economic Democracy, the community is another level at which people would participate in controlling the means of production, through what Schweickart calls "social control of investment". On Schweickart's model, there is no need to rely for investment on private savings (and hence no need to deal with the instability and destruction that too often accompanies such reliance). The funds required for investment are generated through a tax on the capital-the means of production-employed by worker-managed enterprises, a tax that can be understood as the rent enterprises pay to the society that collectively owns the means of production. This rent makes up an investment fund, and parts of it are distributed to communities on a per capita basis, with democratic decision-making at the local level determining how those funds will be invested. ${ }^{17}$ With the funds allocated to communities on a per capita basis and the opportunity for people to determine how to invest their communities' funds, we can expect more participation. As Schweickart explains,

Local politics suddenly becomes more interesting. Citizens have a chance to shape the general structure of their community without having to worry that their decisions may inhibit fresh capital from coming in or cause local businesses to flee. We can anticipate a higher degree of participation by the citizenry in public matters under Economic Democracy than is typical under capitalism. (Schweickart 2002, 152)

Thus Economic Democracy not only provides people with the opportunity to participate in decision-making but also motivates them to do so.

"The point of democracy," Balkin says, "is to put power in the hands of the people, to give ordinary people some measure of control over the forces that shape their lives and some degree of say about how the world around them develops" (Balkin 2004, 36). Implementing Schweickart's democratic form of socialism would do just that. If we slightly modify one of the statements from Balkin quoted towards the beginning of this section, if we replace the term cultural with the term economic, it could be said that democratic socialism of the sort Schweickart proposes would give "ordinary people a say in the progress and development of the [economic] forces that in turn produce them". People having a say in the development of economic forces would not only mean shaping the conditions that shape them. Participating in the process of "having a say" would itself shape them in that it would involve their developing crucial human capacities, among them being the "meta-capability" of "revising one's context" identified by Purdy, the exercise of which "affects the scope of one's future capabilities" and hence contributes to the self-development with which Gould identifies freedom.

Before moving on, I should point out that in this article I do not argue that the problems associated with intellectual property discussed below could be solved simply by having democratic as opposed to capitalist workplaces be in control of the Internet's "pipes," its physical infrastructure. My guess is that before settling upon a particular form of control of that infrastructure, we would have to experiment with different forms of ownership and control of itwith the government treating it as something like a public good ${ }^{19}$, for instance, or with workermanaged firms engaged in market competition but subject to regulation by institutions representing the interests of those outside the firms. ${ }^{20}$ In briefly discussing workplace democracy in this section, I am not saying that all goods and services in a society should be produced and provided only by democratic workplaces. Instead, my aim has been to highlight the principles manifested in a form of socialism that has workplace democracy as one of its central features-the principles of freedom and democracy that take the form of participating in making decisions about the ends that means of production are to serve-because those are the principles I am going to show inform the line of argument about intellectual property made by Lessig and others like him.

\footnotetext{
${ }_{17}^{17}$ For a fuller explanation of how the investment fund is allocated, see Schweickart 2002, 50-56.

${ }^{18}$ For a discussion of more ways in which democratic participation would deepen under market socialism, see Schweickart 2002, 151-56.

${ }^{19}$ Cf. McChesney and Nichols 2010, 101-02.

${ }^{20}$ Cf. Gould 1988, 146.
} 


\section{2.}

In the previous section, I argued that if people are to enjoy freedom and democracy, they must be able to participate in controlling the means of production (in the sense of having a share in decision-making about the purposes to be served by those means), and that socialism is a system that, unlike capitalism, enables and fosters such participation. In this section, I will show that although Lessig does not use the term means of production, he believes that if people are to enjoy freedom and democracy in the cultural sphere-or to have what he sometimes calls "free culture" and at other times "democratic culture"-they must be able to participate in controlling the means of producing culture. What I say in this section, then, lays the groundwork for the analogy, which I draw in Section 3, between the argument made in the previous section about socialist regulation of the means of production in general and Lessig's argument about regulation of the means of producing culture more specifically.

In order to understand Lessig's argument about how to regulate intellectual property, we need, first of all, to clarify what property is and consider the justification typically given for the institution of private property. Many people mistakenly identify property with things when in fact it is a right (or a bundle of rights). As the political philosopher C.B. Macpherson puts it, property is "a right in the sense of an enforceable claim to some use or benefit of something" (Macpherson 2002, 3). The enforceability of such a claim, Macpherson says, depends on whether the claim is justified with respect to a purpose or set of purposes (Macpherson 2002, 11). ${ }^{21}$ One purpose typically appealed to in justifying property rights is that of promoting productivity, and the right that is justified thereby is the right to private property, the right to exclude others from using or consuming the thing in question. ${ }^{22}$ That purpose and that right are implicit in a widely accepted justification of private property that Lessig explains as follows:

The law has good reason [...] to give me an exclusive right over my personal and real property. If it did not, I would have little reason to work to produce it. Or if I did work to produce it, I would then spend a great deal of my time trying to keep you away. It is better for everyone, the argument goes, if I have an exclusive right to my (rightly acquired) property, because then I have an incentive to produce it and not waste all my time trying to defend it. (Lessig, 2006, 181) ) $^{23}$

For the sake of promoting productivity, then, the law grants property owners the right to exclude others from using the things they own. Put differently, the establishment of this legal right is the means by which the end or purpose of promoting productivity is achieved.

In the above passage, Lessig is talking about rights that attach to what he calls "personal and real property," which he elsewhere refers to as "tangible" property. Such "property" is what I will refer to as one kind of object of property rights. Lessig distinguishes between two different kinds of objects of property rights: there are, on the one hand, tangible or physical

\footnotetext{
${ }^{21}$ This isn't quite right. Surely it is easier to enforce a right that the vast majority of people recognize as a justified moral right, but legal rights that are not also moral rights can also be enforced-by way of, say, brute force and perhaps also a little sophistry on the part of lawyers and judges.

${ }^{22}$ What I'm offering here is a very truncated version of a fairly standard, utilitarian or "utility-based" justification of private property rights that justifies those rights on the grounds that exercising them serves the purpose of promoting productivity. One could also employ a "rights-based" argument. In fact, the originators of what Hannibal Travis calls "propertarian ideology"-people like Hobbes, Locke, and Blackstone- "weave together rights-based and utility-based arguments," with the former kind of arguments stressing desert and the latter stressing incentive (Travis 2000 , 8). Readers who want to learn more about the different justifications would do well to read Travis's excellent article.

${ }^{23}$ Blackstone offers a similar explanation of the same justification: "It was clear that the earth would not produce her fruits in sufficient quantities without the assistance of tillage: but who would be at the pains of tilling it, if another might watch an opportunity to seize upon and enjoy the product of his industry, art, and labor?" (qtd. in Travis 2000,14). Consider also Tawney's comments on Bentham: "If I despair of enjoying the fruits of labor,' said Bentham, repeating what were in all essentials the arguments of Locke, 'I shall only live from day to day; I shall not undertake labors which will only benefit my enemies.' Property, it is argued, is a moral right, and not merely a legal right, because it insures that the producer will not be deprived by violence of the result of his efforts" (Tawney 1948 [1920], 55).
} 
objects and, on the other hand, intangible or intellectual objects-ideas. Using the language of economists, Lessig points out that tangible objects are "rivalrous" and intangible objects "nonrivalrous." A rivalrous object is an object that cannot be used or consumed by one person without precluding or reducing the use or consumption of the object by another person. Examples: pants and cake. If I'm the one wearing a pair of pants, you cannot wear those pants at the same time. If I eat a piece of cake, you're not able to eat it too (unless perhaps you're willing to have your cake in a regurgitated form). In the case of nonrivalrous objects like ideas, by contrast, "Your consumption does not lessen mine," as Lessig explains: "If you 'take' my idea, I still have it. [...] If I write a song, you can sing it without making it impossible for me to sing it. If I write a book, you can read a copy of it (please do) without disabling me from reading another copy of it. Ideas, at their core, can be shared with no reduction in the amount the 'owner' can consume" (Lessig 2006, 181-82).

Property rights ought to be different when the thing in question (the object of property rights in question) is intangible rather than tangible-when it's an intellectual object, an idea. That is, although property is a right and not a thing, the kind of right (or set of rights) exercised in relation to the thing should depend on the nature of that thing. ${ }^{24}$ We've already seen above the kind of property right-the right to exclude - that people exercise when it comes to rivalrous objects, the tangible things that make up what Lessig calls "real property". U.S. law grants a different right when it comes to property in ideas (nonrivalrous objects), but[?] the purpose-promoting productivity, albeit productivity with respect to ideas-remains the same. As the "copyright clause" of the U.S. Constitution puts it (article I, section 8, clause 8), the purpose is "to promote the Progress of Science and useful Arts", innovation, in other words. The means by which the purpose or end of promoting innovation is achieved is the establishment for producers of intellectual content of the legal right to exclude others from using it. ${ }^{25}$ However, and this is key, this right can be exercised only for a limited period of time; the right comes with a time limit on the exercise of the right. As stated in the "copyright clause," it is "by securing for limited Times to Authors and Inventors the exclusive Right to their respective Writings and Discoveries" (italics mine) that innovation is to be promoted. In practice, this has meant that producers of intellectual content are granted by the state a monopoly over their ideas for a limited period of time during which they exercise the right to charge people a fee in exchange for giving them permission to make use of those ideas (whether the ideas take the form of a book, song, scientific discovery, etc). Why the limit on the right? The limit is there, Lessig explains, so as to help build and maintain an intellectual commons, the existence of which is in the service of promoting innovation. If people were permitted to exercise the same, temporally unlimited property rights over non-rivalrous objects (ideas) as they do over rivalrous objects, then there would be little or no future innovation. A society where innovators could exercise private ownership over their ideas forever or for lengthy periods of time would cease to be an innovative society. ${ }^{26}$

\footnotetext{
${ }^{24}$ Lessig is among those liberal theorists of intellectual property who apparently subscribes to what Dan Schiller calls the "information exceptionalism hypothesis," the view that intangible objects like information are so different from tangible ones that arguments that apply to regulation of the former do not necessarily apply to regulation of the latter (Schiller 1997). As Söderberg and Daoud explain, people like Lessig set up "a boundary between information and physical goods in order to exclude private property and free markets from their critique of intellectual property" (Söderberg and Daoud 2012, 67). Cf. Pedersen, who argues that "the current politics of the Free Software, Free Culture and cultural environmentalism movements-turning upon misleading conceptions of property relations derived from the economistic distinction between the tangible and the intangible realm-remains a liberal apologia" (Pedersen 2010, 293).

${ }^{25}$ This is not always true, of course. Government entities engaged in the creation of intellectual content need not be incentivized by the prospect of enjoying a monopoly right over that content. Nor should we forget the crucial role played by government-funded research when it comes to the development of innovative technologies, especially those that made the Internet possible (McChesney 2013, 98-101).

${ }^{26}$ This was Thomas Jefferson's worry, as explained by James Boyle: "Jefferson's point was that for the process of invention to work, we need to confine narrowly the time and scope of the state-provided monopoly, otherwise further inventions would become impossible. Each process or part of a new invention would risk infringing a myriad of prior patents on its subcomponents. Innovation would strangle in a thicket of conflicting monopolies with their roots vanishing back in time" (Boyle 2008, 35).
} 
3.

We now have a full enough account of Lessig's ideas to draw an analogy between how he thinks we ought to regulate property in ideas and how socialists think we ought to regulate property in the means of production. We have just seen that Lessig is concerned about preserving the intellectual commons. In this section I show that Lessig's concern has its analogue in the concern socialists have about the (physical) commons. We'll work up to that point by showing that Lessig's argument, like the socialist one laid out in Section 1, is about freedom and democracy and the importance of participation to both, with participation understood to require access to the means of production.

That Lessig's argument is about freedom is evident from his support for what he calls a "free culture." In Free Culture: The Nature and Future of Creativity, Lessig describes a free culture as one that

supports and protects creators and innovators. It does this directly by granting intellectual property rights. But it does so indirectly by limiting the reach of those rights, to guarantee that follow-on creators and innovators remain as free as possible from the control of the past. A free culture is not a culture without property, just as a free market is not a market in which everything is free. The opposite of a free culture is a "permission culture"-a culture in which creators get to create only with the permission of the powerful, or of creators from the past. (Lessig 2004, xiv)

Readers familiar with the distinction between negative freedom ("freedom from") and positive freedom ("freedom to") might think that when Lessig calls for innovators to be "free [...] from the control of the past," he is displaying a concern only for negative freedom, not for positive freedom and hence not for the participatory control of social conditions often championed by those who value positive freedom. But this is not the case. Clarifying what he means by free culture, Lessig says, "not 'free' as in 'free beer' (to borrow a phrase from the founder of the free-software movement [Richard Stallman]), but 'free' as in 'free speech'” (Lessig 2004, xiv). The connection Lessig draws here between free culture and free speech, when combined with what he says about free speech in a later book, Code, suggests that the kind of freedom he has in mind when he talks about free culture is the kind of freedom that has participation as a crucial component. Discussing in Code how the Internet increases people's capacity to exercise free speech, he writes, "The architecture of the Internet, as it is right now [in 2006], is perhaps the most important model of free speech since the founding [of the United States]. [...] Two hundred years after the framers ratified the Constitution, the Net has taught us what the First Amendment means" (Lessig 2006, 237). What he means by this is that the "model for speech that the framers embraced was the model of the Internet-distributed, noncentralized, fully free and diverse" (Lessig 2006, 275). The Internet enables speech of this sort because with the Internet, there is now a "low cost of publishing," which means "publishing is no longer a barrier to speaking" (Lessig 2006, 236) ${ }^{27}$ Prior to widespread access to the Internet, if one wanted to participate in a public conversation by publishing something, one would have to find a publisher, that is, a person or company with ownership of certain instruments for producing and distributing speech. The publisher stood in between the producers and consumers of speech. The Internet enables people to bypass publishers; they can "skip the intermediaries" ${ }^{28}$ For the comparatively low cost of acquiring access to a computer with an Internet connection, people can now acquire access to the instruments of producing and dis-

\footnotetext{
${ }^{27}$ Cf. Lessig 2008, 82-83. Of course, that there is no (or little) barrier to publishing and hence to speaking does not entail that there are no barriers to having one's speech heard (or read) by others. Consider blogs, for example. McChesney observes that "not long ago [blogs] were heralded as 'little First Amendment machines [that] extend freedom of the press to more actors." But as the research of Michael Hindman has revealed, the blogosphere's "traffic is highly concentrated in a handful of sites, operated by people with astonishingly elite pedigrees" (McChesney 196).

28 The phrase "skip the intermediaries" comes from a Creative Commons video called "Get Creative!" See http://creativecommons.org/videos/get-creative (accessed on August 16, 2014).
} 
tributing speech, ${ }^{29}$ which means that many people can participate in shaping their cultural context.

Lessig's argument is about the kind of freedom that is linked to democracy and has as a crucial component the kind of participation that requires access to the means of production. Although Lessig does not use the term means of production, his argument is essentially in favor of widespread access to the raw material of cultural production, with that "raw material" consisting of ideas. ${ }^{30}$ That his argument has to do with democracy and participation that requires access to the raw material of cultural production is clearest in the last book he wrote about the Internet and intellectual property, Remix: Making Art and Commerce Thrive in the Hybrid Economy. There he talks about the importance of establishing what for him appears to be synonymous with free culture, namely, "democratic culture". ${ }^{31}$ Like free culture, democratic culture exists when control of culture is not concentrated in the hands of the few but instead is created and re-created ("remixed", Lessig says) by large numbers of people-in other words, a culture characterized by participation on a wide scale. And he comes very close to saying that this participation requires access to the means of cultural production when he says that widespread participation is made possible when "everyone within a society has access to the means to write" (Lessig 2008, 52; italics mine). Lessig explains that in the case of "writing" as we typically think about it, having access to "the means to write" means being able to quote what others have written or said without first getting their permission to do so; it means having the "freedom to quote, and to build upon, the words of others," a freedom "taken for granted by everyone who writes" (Lessig 2008, 53). In the case of what Lessig calls "writing beyond words," a form of "writing" increasingly common in a world where there is ever-increasing access to audio-visual technology, having access to "the means to write" means being able to use parts of someone else's film in one's own film or use a recording of someone else's song in one's own song-without first getting permission from others to do so (whether those others be the original creators or the lawyers acting on behalf of the companies to whom the original creators have sold off their copyright). ${ }^{32}$ In the case of each of the kinds of "writing" Lessig discusses, then, access to "raw material" that consists of other people's ideas is a requirement if people are to participate in a free and democratic culture.

We come now to the issue of the commons. As noted towards the end of the last section, Lessig supports copyright and thus the privatization of ideas, but he believes there should be limits to this privatization, among them being a limit on the duration of copyright. Both the privatization and the limit on it are in the service of innovation: the promise of privatization is there to incentivize people to innovate, and the temporal limit on privatization is there to ensure there is material that people can draw upon in order to innovate. That material consists of ideas in the intellectual commons, which is required not just for innovation but also culture in general. As Boyle points out, ideas in the intellectual commons are "not some gummy residue left behind when all the good stuff has been covered by property law. The public domain is the place we quarry the building blocks of our culture. It is, in fact, the majority of our culture" (Boyle 2008, 41; italics in original). This means that without a proper limit on the duration of copyright-without proper regulation of the raw material Lessig, Boyle, and others are

\footnotetext{
${ }^{29}$ Of course, not everyone has ready access to a computer linked to the Internet, especially in countries outside the Global North. Moreover, because of policies implemented by Internet service providers (ISPs) that meddle with the original architecture of the Internet, having access to the Internet does not necessarily mean one has ready access to all material available through the Internet. This is something I will discuss in the following section, where I show that we must pay attention to privatization of not just the raw material of cultural production but also the instruments of cultural production and distribution.

${ }^{30}$ Boyle employs an image of ideas as raw material when he speaks of the public domain being "the place we quarry the building blocks of our culture" (Boyle 2008, 41).

${ }^{31}$ Boyle (2008) appears to have more or less the same concept in mind when he speaks of "democratic creativity" and the "democratization of creativity."

32 Lessig writes, "Though I've not yet found anyone who can quite express why, any qualified Hollywood lawyer would tell you there's a fundamental difference between quoting Hemingway and quoting Sam Wood's [film] version of Hemingway". According to Lessig, "The act is the same; only the source is different. And the measures of fairness could also be the same: Is it really just a quote? Is it properly attributed? And so on" (Lessig 2008, 53).
} 
so concerned about-it's not just innovation that would suffer. So too would culture-or rather so too would people's participation in shaping their culture. Unfortunately, as Lessig, Boyle, and many others have shown, over the past many years the temporal limit on copyright has been eroded and with it the intellectual commons. Over the past two centuries, copyright terms have been extended significantly-from 28 years in 1790 (14 years with an opportunity to renew for another 14 years); 42 years in 1831; 56 years in 1909; life of the author plus 50 years, or 75 years for works of corporate authorship, in 1976; to life of the author plus 70 years, or 95-120 years for works of corporate authorship, in 1998. ${ }^{33}$

The process of privatizing the intellectual commons that has been taking place at an increasingly rapid rate over the past several decades can be understood as a process of enclosure. Along with a number of other scholars, Boyle speaks of what is happening to the intellectual commons as a "second enclosure movement", drawing parallels between it and the first enclosure movement that took place in England between the fifteenth and nineteenth centuries. ${ }^{34}$ Whereas the first enclosure movement consisted of enclosure of the physical commons, more specifically, the enclosure of land, the second has consisted of enclosure of the intellectual commons. When there is enclosure of land, those who want to produce the means of life-food, in other words-lack access to the land, which contains the raw material required to produce those means. Analogously, when there is enclosure of the intellectual commons, those who want to produce new ideas-those who wish to innovate, to participate in shaping their cultural context-lack access to the ideas from past creations, which are the raw material or, to use Boyle's language, the "inputs of future creation" (Boyle 2008, 40).

It might seem that we have reached the limits of the analogy that can be drawn between Lessig's line of argument and the one presented in Section 1. It might seem that although the concepts of freedom, democracy, participation, access to means of production, and reversing enclosure of the commons are key to the lines of argument developed by Lessig and socialists alike, there is one significant point of divergence: the commons each has in mind are made up of very different things. The commons Lessig, Boyle, and other liberal theorists of intellectual property speak of is populated by ideas, which are intangible and nonrivalrous, whereas the commons socialists talk about consists of things that are tangible and rivalrous. Given this difference, it might seem there is no inconsistency in the position I attribute to Lessig and others like him, namely, that the nonrivalrous means of production that consist of ideas should be common property whereas the rivalrous means of production that consist in, say, land, tools, machinery, and so forth should be private property. Reasoning to support this position might look something like the following: there is no problem with nonrivalrous things being common property (whether after being copyrighted for a period of time or not ${ }^{35}$ ) since one person's use of a nonrivalrous thing does not diminish the use of that very same thing by other people; by contrast, there is a problem with common ownership of rivalrous, tangible things like land, tools, and machinery because one person's use of such things does diminish the use of those same things by others; therefore, it is best to have the latter sort of things be privately owned-for the reason (mentioned in Section 2) given by Lessig, namely, that in a world where no one is prevented from taking rivalrous things produced by others, one would either have no incentive to produce such things or else would produce such things but then spend too much time defending them from others. One does not have to believe in something like Garret Hardin's "tragedy of the commons" thesis to see that there would be problems if use of rivalrous means of production were regulated the same way use of ideas

\footnotetext{
${ }^{33}$ The former Motion Picture Association of America president Jack Valenti proposed that the term of copyright be defined as "forever less one day", which he figured was technically in keeping with the copyright clause's call for securing for authors and inventors an exclusive right to their respective writings and discoveries for a limited period of time. For an explanation of how Valenti's "wish has essentially been granted", see Hyde 2010, 59 and Lessig 2004, 252.

${ }^{34}$ Cf. Balkin's observation that we are also "living through a Second Gilded Age, which, like the first Gilded Age, comes complete with its own reconstruction of the meaning of liberty and property" (Balkin 2004, 25).

${ }^{35}$ As we've seen, liberal theorists worry that there wouldn't be many things of value to hold in common unless people can be incentivized to produce those things in the first place, hence, the promise of private ownership of those things by those who produce them, albeit for a limited period of time.
} 
in the intellectual commons is. ${ }^{36}$ If rivalrous means of production were common property as defined by Macpherson, that is, things everyone has the right not to be excluded from (Macpherson 1978, 4), and people could make use of them without first obtaining permission from other individuals or some governing body regulating people's use of those means of production, then in all likelihood they would rapidly fall into disrepair.

However-and this is why the analogy I have been pressing remains intact despite the difference between things that are nonrivalrous (ideas, which are intangible) and rivalrous (tangible means of production)-democratic control of what I will call instruments of cultural production is required if we are to promote the free and democratic culture Lessig and others like him call for. To see that this is the case, it helps to observe that ideas are not their own means of production-or rather, they are, but in the digital age, their production almost always depends on means of production that, unlike ideas, are rivalrous. For the production and distribution of ideas qua products, more is needed than ideas qua raw material. Ideas qua raw material of course constitute one of the requisite means of producing ideas qua products, which is to say that ideas qua raw material are one of what Lessig calls "the means to write", but there is another kind of means of production, another "means to write", without which certainly the distribution, and in plenty of cases also the production, of culture is severely limited. These are instruments of cultural production. They, together with the raw material consisting of ideas, make up the means of cultural production.

Chief among the instruments of cultural production are networked computers. Benkler observes that "[p]ersonal computers and network connections are ubiquitous" nowadays, which means "the physical capital required for production [of ideas] is broadly distributed throughout society" (Benkler 2006, 6). Except for in certain rural and poverty-stricken areas, computers are indeed widely available in the U.S. (as well as in other countries that constitute the periphery of global capitalism). However, access to the network of computers-to the Internet-is becoming increasingly privatized. This is most obviously the case when we look at control of the Internet's "pipes," which constitutes "the medium of transmission, whether it be spectrum, networks, telephone wires, or cables" (Balkin 2004, 17). ${ }^{37}$ Increasingly these pipes are controlled by fewer and fewer companies, with monopoly conditions reigning in the telephone and the cable television industries regardless of whether their services are delivered by wire or wirelessly (Chester 2007, 182-91; McChesney 2013, 109-20). Referring to the latest noteworthy development in this area, the 2011 merger of Comcast with NBC, which they call "the first great merger of the new era", Foster and McChesney make the following prediction: "The future increasingly looks like one where the wireless Internet world will come to equal or exceed the traditional wireline broadband sector, and this will be a proprietary system that does not practice 'network neutrality' or have the openness long associated with the Internet" (Foster and McChesney 2011). ${ }^{38}$

The term network neutrality that Foster and McChesney use here refers to the policy that has been in place since the advent of the Internet, where regardless of the "platform" one uses-regardless of whether one uses, for example, Facebook to blog or some much lesserknown blogging platform, or uses YouTube rather than a non-profit website to post a videothe content one wishes to distribute is accessible to everyone with access to the Internet. This policy has not been enshrined in law, however. As Rebecca MacKinnon explains in Consent of the Networked, "Currently in most countries, there is no law preventing Internet servicing providers [ISPs] from discriminating between services for a profit: your ISP could in theory offer a 'tiered' access package in which access to certain services belonging to major

\footnotetext{
${ }^{36}$ One would do well not to believe in Hardin's thesis, which is based on the mistaken assumption that the capitalist imperative is inscribed by nature in the soul of every person. Hardin's thesis has been subject to considerable criticism over the years, with the late Elinor Ostrum being among the most prominent critics. For a relatively brief critique of the thesis, see Chapter 6, "We are all Commoners," in Raj Patel, The Value of Nothing (2009).

${ }^{37}$ It's not just the pipes but also the code and "architecture" of the Internet that are being manipulated to serve the interests of powerful companies. Showing that this is the case would require going into technical details that would extend the length of this paper considerably. Excellent analyses can be found in Lessig 2001, Lessig 2006, and van Schewick 2010.

${ }^{38}$ Cf. Chester 2007, 182-91.
} 
brand names (Amazon, Netflix, YouTube, and Facebook, for example) would be cheaper than access to the general Internet or to lesser known applications" (MacKinnon 2012, 118). ${ }^{39}$ The Federal Communications Commission (FCC) preserved net neutrality to an extent in December 2010, when it issued rules prohibiting ISPs from discriminating between platforms or services on wireline broadband, but it exempted wireless broadband providers from these rules-at a time when, as MacKinnon notes, "Much of the Internet's growth is happening through mobile phones, not through laptops or desktops connected to [wireline] broadband" (MacKinnon 2012, 123; cf. McChesney 2013, 119-20). With more mergers of the Comcast-NBC sort likely in the future along with continued dismantling of net neutrality, we are on the path toward a "nonneutral net" ${ }^{40}$ MacKinnon explains that with such a network, "in which platforms and applications must compete by paying fees to gain maximum access to Internet users-and in which Internet users are asked to pay different amounts for different tiers of access determined by the different deals the ISP has cut with the companies that run different services and platforms-citizens will depend all the more on large, well-financed, commercially operated platforms to carry out political discourse and political organizing" (MacKinnon 2012, 118). ${ }^{41}$

Erosion of the "openness long associated with the Internet" that Foster and McChesney fear we are now witnessing was foreseen by Lessig back in 2001, when he described the future we are making as follows: "Take the Net, mix it with the fanciest TV, add a simple way to buy things, and that's pretty much it. It is a future much like the present. [...] What gets offered will be just what fits within the current model of the concentrated systems of distribution: cable television on speed, addicting a much more manageable, malleable, and sellable public" (Lessig 2001, 7). The promotion of commercial speech and in some cases outright censorship of political speech that might challenge the dominance of commerce (MacKinnon 2012, 116-22) impacts the kind of culture that exists. Instead of the participatory culture that Internet technology enables, we get the exclusionary culture one would expect from widespread privatization, which is by definition about exclusion. If this is the future, how to stop it? ${ }^{42}$

\section{4.}

Several years ago, the Creative Commons organization-of which both Lessig and Boyle were co-founders-encouraged people to "skip the intermediaries". It did this by providing creators of intellectual content with a set of copyright licenses they could use to clearly indicate the uses to which other people could put that content. As the organization's website explains, when you use a Creative Commons license, "you keep your copyright but allow people to copy and distribute your work provided they give you credit". ${ }^{43}$ Depending on the

\footnotetext{
39 An example of this-Comcast's shakedown of Netflix in late 2013, early 2014-is amusingly portrayed in a famous clip from John Oliver's Last Week Tonight, one credited with exposing a great number of people in the U.S. to the issue of net neutrality. The clip can be found here: https://www.youtube.com/watch?v=fpbOEoRrHyU (accessed on August 6, 2014).

${ }^{40}$ As I finish writing this article, the U.S. is being taken down this path by Tom Wheeler, currently FCC Chair and formerly a cable and wireless industry lobbyist. Former FCC Chair and current President and CEO of the National Cable and Telecommunications Association, Michael Powell, wants to move the Internet in much the same direction. The efforts of Wheeler, Powell, and their (largely corporate) backers have met staunch opposition in the form of citizen action organized by the likes of Free Press and the Electronic Frontier Foundation.

${ }^{41}$ MacKinnon provides a number of disturbing examples ISPs interfering with political organizing and discourse, among which were the following two in 2007: (1) Verizon Wireless blocking text messages sent out by NARAL Pro-Choice America to its supporters and (2) AT\&T, "during a live-streaming broadcast of a Pearl Jam concert," muting "the sound when lead singer Eddie Vedder made comments critical of then-president George W. Bush" (MacKinnon 2012, 116-17). For more on the sorts of restrictions ISPs can place on Internet activity, see Lessig 2004, 156-58.

${ }^{42}$ My phrasing here is a remix of the title of Jonathan Zittrain's book, The Future of the Internet-And How to Stop It (2009).

43 Source: http://www.creativecommons.be/node/2 (accessed on August 16, 2014). As Lessig explains, "Creative Commons offers copyright holders a simple way to mark their creative work with the freedoms they intend it to carry. That mark is a license which reserves to the author some rights, while dedicating to the public rights that
} 
license you select, people are permitted to alter your work or not, use it for commercial purposes or not, and so on. With these legal tools that Creative Commons provides, it is possible to create a non-privatized pool of raw material that it is easy for people to draw frommuch more easily than people can draw from material fenced in by the standard copyright license and too often protected by numerous "intermediaries", that is, copyright holders and their lawyers. As we have seen, there is another sense in which we can "skip the intermediaries": prior to widespread use of the Internet, producers of intellectual content were separated by publishers from consumers of that content, but with a computer and Internet access, one can bypass the publisher; the publisher is an intermediary one can now skip. However, as we just saw in Section 3, copyright holders, lawyers, and publishers are not the only intermediaries we need to be concerned about. There are, in addition, the intermediaries who control people's access to the Internet by controlling the "pipes".

Privatization of the latter is unlikely to let up. When they wrote their March 2011 article about the Internet's "unholy marriage" with capitalism, Foster and McChesney announced that we could "expect more great mergers among and between the largest media, telecommunication, computer, and Internet corporations, along the lines of Comcast-NBC". "Developments since that announcement confirm their worry, ${ }^{45}$ with privatization of the means of cultural production unlikely to let up in the future. ${ }^{46}$ Attempts to legislate against these developments are unlikely to succeed. Lessig himself admitted as much in The Future of Ideas and Code. ${ }^{47}$ As he sees it, until we solve the problem of legislators being corrupted by money, we will not achieve a free culture. Hence his recent work on the issue of corruption (Lessig 2011). ${ }^{48}$ Corruption, he says, is at the root of so many of the problems we currently face. Referencing a statement made by Thoreau, he says we must become "rootstrikers". We must strike at the root of our problems. However, corruption isn't the real root of our problems. Thus Lessig's analysis and proposals, though excellent, are not radical enough (recall here that the word radical has as its root the Latin term radix, which means "root"). ${ }^{49}$ The real root is the process of accumulation under capitalism, a process that, so long as capitalism exists, will exert enormous pressure against efforts to curb the privatization of whatever it is profitable to privatize..$^{50}$

We mustn't forget that capitalism is an obstacle to more than just a free culture. Capitalism goes hand in hand with creating poverty, increasing inequality, maintaining unemployment, overworking the employed, undermining democracy, damaging the environment, and encouraging imperialism. ${ }^{51} \mathrm{~A}$ solution sufficiently radical to address all of these problems is

otherwise would have been held privately. As these licenses are nonexclusive and public, they [...] effectively build a commons of creative resources that anyone can build upon" (Lessig 2006, 199).

${ }^{44}$ Foster and McChesney 2011.

${ }^{45}$ A number of troubling developments have taken place since the publication of Foster and McChesney's article. One of them was Verizon's purchase of spectrum from the Cox Communications cable company as well as from SpectrumCo, a company that Comcast owns a majority of. Those two purchases have created a duopoly in the wireless market, with AT\&T being the other major player. See Ludwig 2012.

${ }^{46}$ Smith offers an intriguing explanation in support of this claim about future developments as they relate to the raw material of cultural production. See what he says about the likely effects of what he calls one of "the most distinctive features of global capitalism today," namely, "the unprecedented number of reasonably effective national innovation systems" (Smith 2012, 177-78).

${ }^{47}$ See, for instance, Lessig 2006, 167-68 and 313-24.

${ }^{48}$ His work on the issue is not confined to writing books. As was the case when he was writing books about the Internet-during which time he helped found and run Creative Commons-he has in recent years helped to found and run See also the website Lessig helped to found the anti-corruption organization Root Strikers (http://www.rootstrikers.org/).

49 The same may be said of Boyle's proposal to create something like the environmental movement, what he refers to as "cultural environmentalism", "an environmentalism for information", and "an environmentalism of the mind". See, for example, Boyle 2008, 230-48. The idea is ingenious but suffers from the same problem that mainstream environmentalism does, namely, failure to call for the abolition of capitalism. For an explanation of why environmentalists should be anti-capitalist, see Magdoff and Foster, 2011.

50 The capitalist process of accumulation is a process of overaccumulation, and whenever there is overaccumulation, there is enormous pressure to privatize public forms of wealth. For a discussion of this process as it relates to enclosing the commons, see Harvey 2003, 137-82.

${ }^{51}$ For a discussion of the first six features of capitalism, see Schweickart 2002, 87-126. For a discussion of the last point, see Parenti 1995, 1-17. 
one that involves skipping the most important intermediary of all, the capitalist class. This we can do by democratizing control of the means of production along the lines laid out in Section 1. What exactly a free, democratic, and participatory culture would look like if we also had a free, democratic, and participatory economy would be up to the people who would build both. ${ }^{52}$ One of the instruments of cultural production we have looked at in this paper-the Internet's "pipes"-would most likely become a form of common property, which is to say resources that everyone has the right not to be excluded from using. ${ }^{53}$ Perhaps the same would happen with the raw material consisting of ideas, though it's also possible that people would elect to have those resources regulated the way the Founding Fathers had in mind, that is, through the system of copyright that Lessig describes as communist. ${ }^{54}$ In any event, it seems that if communism or socialism or some other promising-so long as essentially noncapitalist-system is at the core of how we organize our social activity, we increase the likelihood of living in a society that protects freedom, democracy, and participation.

\footnotetext{
${ }^{52}$ For a brief sketch of what such a world could look like, see Smith 2012, 179.

${ }^{53}$ The particular form of common property it would likely assume is that of a public good. For a discussion of the Internet (and, by implication, access to it) as a public good, see McChesney 2013, 51-53.

${ }^{54}$ For recent, promising experiments in regulating ideas in a way different from what is laid out in the copyright clause of the U.S. Constitution and that diverges as well from the proposals for "free culture," see the discussion of "open cooperatives" in Winn 2015, 13-16.
} 


\section{References}

Albert, Michael. 2003. Parecon: Life After Capitalism. London and New York: Verso.

Balkin, Jack. 2004. Digital Speech and Democratic Culture: A Theory of Freedom of Expression for the Information Society. N.Y.U. Law Review, 79: 1 (2004), 1-55, 17.

Benkler, Yochai. 2006. The Wealth of Networks: How Social Production Transforms Markets and Freedom. New Haven and London: Yale University Press.

Boyle, James. 2008. The Public Domain: Enclosing the Commons of the Mind. New Haven and London: Yale University Press.

Boyle, James. 1997. A Politics of Intellectual Property: Environmentalism for the Net? Duke Law Journal 47.

Braverman, Harry. 1998 (1974). Labor and Monopoly Capital: The Degradation of Work in the Twentieth Century. New York: Monthly Review Press.

Chester, Jeff. 2007. Digital Destiny: New Media and the Future of Democracy. New York and London: The New Press.

Cohen, G. A. 1978. Karl Marx's Theory of History: A Defence. Princeton: Princeton University Press.

Dewey, John. 1999 (1930). Individualism Old and New. Amherst and New York: Prometheus Books.

Foster, John Bellamy and Robert McChesney. 2011. The Internet's Unholy Marriage to Capitalism. Monthly Review 62, March 2011 (http://monthlyreview.org/2011/03/01/the-Internets-unholymarriage-to-capitalism; accessed on November 29, 2012).

Gould, Carol. 1988. Rethinking Democracy: Freedom and Social Cooperation in Politics, Economy, and Society. Cambridge: Cambridge University Press.

Hardt, Michael and Antonio Negri. 2004. Multitude: War and Democracy in the Age of Empire. New York: Penguin Books.

Harvey, David. 2003. The New Imperialism. Oxford: Oxford University Press.

Howard, Michael W. 2000. Self-Management and the Crisis of Socialism: The Rose in the Fist of the Present. Lanham, Boulder, New York, and Oxford: Rowman \& Littlefield Publishers, Inc.

Hyde, Lewis. 2010. Common as Air: Revolution, Art, and Ownership. New York: Farrar, Straus, and Giroux.

Jossa, Bruno. 2014. Producer Cooperatives as a New Mode of Production. New York: Routledge.

Kotz, David M. 2002. "Socialism and Innovation." Science and Society 66: 1 (Spring), 94-115

Lessig, Lawrence. 2001. The Future of Ideas: The Fate of the Commons in a Connected World. New York: Vintage Books.

Lessig, Lawrence. 2004. Free Culture: The Nature and Future of Creativity. New York and Toronto: Penguin

Books.

Lessig, Lawrence. 2006. Code: Version 2.0. New York: Basic Books.

Lessig, Lawrence. 2008. Remix: Making Art and Commerce Thrive in the Hybrid Economy. New York: Penguin Press.

Lessig, Lawrence. 2011. Republic, Lost. New York and Boston: Twelve.

Ludwig, Mike. 2012. "Consumer Groups: Verizon's Cozy Deal With Cable Would Create Market Duopoly." Truthout, April 3, 2012 (at http://www.truth-out.org).

MacKinnon, Rebecca. 2012. Consent of the Networked: The Worldwide Struggle for Internet Freedom. New York: Basic Books.

Macpherson, C.B. 2002 (1978). Property: Mainstream and Critical Positions. Toronto: University of Toronto

Press.

Magdoff, Fred and John Bellamy Foster. 2011. What Every Environmentalist Needs to Know About Capitalism. New York: Monthly Review Press.

McChesney, Robert. 2013. Digital Disconnect: How Capitalism is Turning the Internet Against Democracy. New York: The New Press.

McChesney, Robert and John Nichols. 2010. The Death and Life of American Journalism: The Media Revolution That Will Begin the World Again. Philadelphia, PA: Nation Books.

Mosco, Vincent. 2004. The Digital Sublime: Myth, Power, and Cyberspace. Cambridge, MA: MIT Press. 
Nussbaum, Martha. 2011. Creating Capabilities: The Human Development Approach. Cambridge, Massachusetts: Belknap Press of Harvard University Press.

Ollmann, Bertell, ed. 1998. Market Socialism: The Debate Among Socialists. New York and London: Routledge.

Parenti, Michael. 1995. Against Empire. San Francisco: City Lights Books.

Pedersen, Martin. 2010. Property, Commoning and the Politics of Free Software. The Commoner 14.

Perelman, Michael. 2002. Steal this Idea: Intellectual Property Rights and the Corporate Confiscation of Creativity. New York: Palgrave Macmillan.

Purdy, Jedidiah. 2005. A Freedom-Promoting Approach to Property: A Renewed Tradition for New Debates. Duke Law School Faculty Scholarship Series 14: 47-48. http://lsr.nellco.org/duke fs/14 (accessed on November 29, 2012).

Schiller, Dan. 1997. The Information Commodity: A Preliminary View. In: Cutting Edge: Technology, Information Capitalism and Social Revolution, edited by Jim Davis, Thomas A. Hirschl, and Michael Stack, 103-120. London: Verso.

Schiller, Dan. 2006. How to Think About Information. Urbana: University of Illinois Press.

Schweickart, David. 1996. Against Capitalism. Boulder: Westview Press.

Schweickart, David. 2002. After Capitalism. Lanham, Boulder, New York, and Oxford: Rowman \& Littlefield

Publishers, Inc.

Smith, Tony. 2012. Is Socialism Relevant in the 'Networked Information Age'? A Critical Assessment of The Wealth of Networks. Anatole Anton and Richard Schmitt (eds.), Taking Socialism Seriously. Lanham, Maryland: Lexington Books, 157-86.

Suarez-Villa, Luis. Technocapitalism: A Critical Perspective on Technological Innovation and Corporatism. Philadelphia: Temple University Press, 2009.

Tawney, R. H. 1948 (1920). The Acquisitive Society. New York: Harcourt, Brace, \& World.

Travis, Hannibal. 2000. Pirates of the Information Infrastructure: Blackstonian Copyright and the First Amendment. Berkeley Technology Law Journal 15 (2000): 789-803.

van Schewick, Barbara. 2010. Internet Architecture and Innovation. Boston: The MIT Press.

Wolff, Richard. 2012. Democracy at Work: A Cure for Capitalism. Chicago: Haymarket Books.

Young, Iris. 1990. Justice and the Politics of Difference. Princeton: Princeton University Press.

Zittrain, Jonathan. 2009. The Future of the Internet-And How to Stop It. New Haven: Yale University Press.

\section{About the Author}

Forrest Perry

Forrest Perry earned his B.A. from Wesleyan University (Middletown, CT) and his Ph.D. from Vanderbilt University (Nashville, TN). An associate professor in the Department of Philosophy at Saint Xavier University (Chicago, IL), he specializes in social and political philosophy, with research and teaching interests in issues related to political economy, race, education, and the environment. 